\title{
Conversion of Dermal Proteins of an Algerian Ovine to an Antimicrobial Agent for Skin Lesion
}

\author{
Tabak Messekine Djamila ${ }^{1}$, Meddah Boumediene ${ }^{1,2}$ and Sonnet Pascal $^{2}$ \\ 1. Bioconversion Laboratory, Microbiological Engineering and Sanitary Safety, Faculty of Natural Sciences and Life, University of \\ Mascara, Mascara 29000, Algeria \\ 2. Laboratory Glycochemistry of Antimicrobials and Agroressources (LG2A) UMR 7378 CNRS, University of Picardie, Amiens \\ 80000 , France
}

\begin{abstract}
The aim of this study was the conversion of the ovine dermal proteins as a natural product that has an antimicrobial power which used for tissue repair and skin lesion. After dehairing, fleshings, deliming the animal tissues (ovine) and purification, the essential oils of Lavandula officinalis, Eucalyptus globules and Eugenia caryophyllata had been supplied and fixed. The product obtained is a spongy material communicating with open voids between the fibers. With a transparent light yellow color, it has a remarkable antibacterial power and a very strong inhibitory activity on all the bacterial strains tested whose average diameter of the inhibition zones exceeds $16 \mathrm{~mm}$. It is also characterized by a smell which can be aromatic, pleasant and spicy or fresh and spicy depending on the essential oil used.
\end{abstract}

Key words: Conversion, essential oils, ovine dermal proteins, natural substance, medical purposes.

\section{Introduction}

The extraction technique of proteins and their preparation as biodegradable products from animal skins are well known for many years in medicine for the treatment of wound and the pathological cavity in the bones [1-3]. However, these products raise always a problem of potential transmission of an infectious agent, known or unknown, despite the severity of manufacturing and control procedures [4]. Some studies have been carried out actually to eradicate this problem from different antibiotics known by their antibacterial effect as it is the case for the gentamicin compress [5-7]. At the end of the 1980s and in the 1990 s, this process began to be no longer regarded as a miracle as it seems to be 40 years earlier. Indeed, many bacteria have developed a resistance to most antibiotics, thus, it seems important to find another alternative. Studies have shown that essential oils

Corresponding author: Tabak Messekine Djamila, assistant Ph.D., main research field: conversion of proteins an biomatérials for medical purposes. could be a particularly credible application. Antimicrobial activity of essential oils is known empirically since antiquity [8]. Their effectiveness as anti-infection was scientifically established in vitro and in vivo. They have a genuine spectrum anti-infectious including isolated cases of resistant infection to antibiotics [9]. Thus, the present study is looking into the preparation of an antimicrobial product based on ovine dermic protein powered by essential oils. This preparation is followed by tests of antimicrobial activity on the finished product.

\section{Material and Methods}

\subsection{Dermic Protein Preparation}

The dermic protein preparation and transformation procedure was carried out from 24 months-aged north Algerian (Mascara region) mortal remains ovine, in the manner described below [10].

\subsubsection{Cleaning}

The ovine skin, a weight of $5 \mathrm{~kg}$, was soaked in four of its weights in an aqueous solution of sodium 
chloride $5 \%$ to $15 \%$, containing about 0.2 parts to 1 parts by weight of sodium azide as a preservative per 1,000 parts by weight of the particular solution, and $0.5 \%$ to $2 \%$ by weight of nonionic fat material-a dispersing agent and a wetting agent (polyoxyethylene nonyl phenol ether), at a temperature ranging from $18{ }^{\circ} \mathrm{C}$ to $20{ }^{\circ} \mathrm{C}$ for 24 hours in a fuller, to remove impurities and stains.

\subsubsection{Removal of Wool}

Hairs are removed with a pelain bath, containing 4 weight parts with regards to the lime mortal remain weight $0.1 \mathrm{M}$, with a temperature from $18{ }^{\circ} \mathrm{C}$ to $20^{\circ} \mathrm{C}$ for 48 hours. The $\mathrm{PH}$ of the solution must be ranging between 12 and 13.5 in a fuller.

\subsubsection{Hypoderm Elimination}

The subcutaneous tissue is eliminated mechanically with a defleshing instrument. The blades of the machine cylinder plane the subcutaneous tissue, which constitute an alcaline and a lot hydrated waste, called "carnasse".

\subsubsection{Decalcifying}

The defleshed tissue, consisting of 2 parts of its new weight, is soaked in a bath of a mixture of $2 \mathrm{~g} / \mathrm{L}$ of ammonium sulfate and $0.5 \mathrm{~g} / \mathrm{L}$ of sodium metabisulfite. This procedure is required to eliminate the alcaline products combined to dermic proteins.

The obtained pulp after these operations has a whitish color. One $\mathrm{kg}$ of it has been processed according to the Piter and Ries method [11], consisting:

Crushing: frozen from $-10{ }^{\circ} \mathrm{C}$ to $-20^{\circ} \mathrm{C}$, and finely crushed by means of a high-speed homogenizing knife. The temperature of the crushed matter has been kept below $4{ }^{\circ} \mathrm{C}$ by adding ices;

Paste cleaning: put in suspension and shaked up strongly, at the same time, in order to wash well the paste in the 5 parts of its volume, in acetic acid at 0.5 $M$ and centrifuged;

Digestion: the solid centrifugal has been put in suspension in 5-litre acetic acid at $3 \%$, containing $1 \mathrm{~g}$ of technic pepsine for 1,000 weight parts tissue, used as starting matter in $100 \mathrm{~mL}$ of $\mathrm{HCl}$ at $0.01 \mathrm{~N}$, in order to eliminate noncollagenous-type proteins and telopeptids. The suspension $\mathrm{pH}$ has been adjusted at 2.9 by means of $\mathrm{HCl}$. The repeatedly shaken suspension is digested for 48 hours, the visquous ovine dermic protein solution was filtered by up filter, in order to eliminate non degraded residues.

Precipitation: the Ovine dermic proteins visquous filtrate was precipitated from the suspension by adding an aqueous solution of sodium hydroxide at $30 \%$ and separated by centrifugation;

Purification: Ovine dermic proteins were purified by dissolution in acetic acid at $0.5 \mathrm{M}$ and precipitated by slow adding of $3 \%$ of aqueous sodium chloride;

Dissolution: Purified Ovine dermic proteins have been dissolved in acetic acid at $0.5 \mathrm{M}$ and diluted in water. Residual sodium chloride present in the proteins has been eliminated by cleaning using an ultrafilter.

Ultrafiltration was carried on till the chloride ion undetectable in the eluate after adding silver nitrate. The concentration of proteins increases to almost $2 \%$;

Freeze-drying: the ovine dermic protein solution was filtered and poured in glass boxes and freeze-dried at $0.3 \mathrm{~cm}$ in thickness;

Thermal processing: the semi-finite product has been heated to $100{ }^{\circ} \mathrm{C}$ for an hour and half in a electrically heated drying classical oven, in order to improve its absorption and resistance against dampness, and then sterilized by irradiation with a dose of 2.5 billion of $\gamma$ rays.

\subsection{Dermic Protein Transformations}

\subsubsection{Feeding}

It was divided into four parts. Each part is fed with essential oil, with a repeated tender shake for half an hour to allow seepage and fixation of essential oils, except the last part which remains as a witness (Table 1).

\subsubsection{The Used Oils}

The used oils were lavender, clove and eucalyptus (Table 2). The used amounts depends on the minimum 
inhibitory concentration threshold, which was defined as the lowest concentration of oil capable of inhibiting bacterial growth [12]. Finally, the dampened products were packed in thermo-sealed polyethylene bags.

\subsection{Biological Materials}

Bacterial strains: to estimate the anti-microbial activity, it has been used wild strains and reference strains widely met in many human pathologies. Tests are performed on five bacteria from Pasteur Institute (Algeria) (Table 3).

\subsection{Anti-bacterial Activity Assessment}

The anti-bacterial activity assessment of various groups has been measured by the aromatogram technique, similar to that of the antibiogram used to test antibiotics [13].

It has been used ovine dermic protein discs (products) of various groups of $5 \mathrm{~mm}$ in diameter, put on the surface of a Mueller-Hinton gelosed environment. It's a standardized environment according to WHO standard, in the way, it allows the growth of many bacteria.
The environment is aseptically sown by $1 \mathrm{~mL}$ of suspension of each strain by using STRIS method. Boxes are pre-dryied before used [13, 14]. The petri dishes are incubated in an oven at $37^{\circ} \mathrm{C}$ for 24 hours.

The effect of the product is seen by the formation of an inhibition halo around the disc. The reading of the results is made by the measure of the inhibition diameter (in $\mathrm{mm}$ ) by means of a caliper rule or a ruler. Essential oils dilution on the ovine dermic protein discs always happens in a solvent such as glycol ethylene, ethanol at $95 \%[15,16]$.

The principle of this method is always the essential oil migration by the diffusion in the gelose. This technique inspired from that of the antibiograms has been generalized to HE [17]. A product is said active if it has an inhibition diameter greater or equal to 15 $\mathrm{mm}[18]$.

\section{Results}

The transformation of the ovine dermic proteins allowed to obtain a product which has a biodegradable spongy structure, communicating with open spaces between fibers.

Table 1 Supply formula of dermal ovine proteins.

\begin{tabular}{lll}
\hline Batchs & Essential oil (\%) & Vaseline (\%) \\
\hline 1rst batch Eucalyptus globulus & 0.1 & 10 \\
2nd batch Eugénia caryophyllata & 0.1 & 10 \\
3rd batch Lavandula officinalis & 0.8 & 10 \\
4rth batch without essential oil & 0 & 10 \\
\hline
\end{tabular}

* Percentages are relative to the weight of ovine dermal protein (semi-finite product).

Table 2 Characteristics and chemical constituents of essential oils.

\begin{tabular}{|c|c|c|c|c|c|}
\hline Essential oil & Color & Smell & \multicolumn{2}{|c|}{ Main chemical constituents $(\%)$} & Aspect \\
\hline Eucalyptus globulus & Very pale yellow & Fresh and spicy & Eucalyptol & $70 \%$ & Liquid \\
\hline Eugénia caryophyllata & Light yellow & Pleasant and spicy & Eugénol & $78 \%$ & Liquid \\
\hline Lavandula officinalis & Light yellow & Aromatic & $\begin{array}{l}\text { Linalool } \\
\text { Linalyl ace }\end{array}$ & $\begin{array}{l}51 \% \\
19 \%\end{array}$ & Liquid \\
\hline
\end{tabular}

Table 3 Bacterial strain.

\begin{tabular}{llll}
\hline Strain name & Reference & Gram & Family \\
\hline Staphylococcus aureus & ATCC6538 & + & Microccaceae \\
Escherichia colis & ATCC25922 & - & Enterobacteriaceae \\
Pseudomonas Aeruginosa & ATCC10145 & - & Pseudomonaceae \\
Klebseilla pneumoniae & Sauvage & - & Enterobacteriaceae \\
Salmonella heiderlberg & Sauvage & - & Enterobacteriaceae \\
\hline
\end{tabular}


The product obtained after deliming has a little bit white color (Fig. 1), on the other hand, the semi-finished product has a very white color (Fig. 2).

After supply and fixation of various types of essential oils, the color of the product turns on transparent clear yellow as seen in Fig. 3 with a spicy, fresh aromatic or pleasant spiced smell depending on the nature of essential oil used.

The study of the antibacterial power of products (ovine dermic proteins) fed by Eucalyptus globulus, Eugénia caryophyllata and Lavandula officinalis was made by the method of spreading on gelose. The measure of the diameter of the inhibition zones including the disc of the product $(5 \mathrm{~mm})$ allowed to determine the antimicrobial activity of them in vitro products. Table 4 shows the results of the average antimicrobial activity tests of the various batch on bacterial strains of Staphylococcus aureus, Escherichia coli, Pseudomonas Aeruginosa, Klebseilla pneumoniae and Salmonella heiderlberg.

\section{Discussion}

Note that the essential oils were easily absorbed into the product. According to Dorman H. J. D., and Deans S. G. [19], active essential oils contain secondary metabolism components that are small enough to pass through the protein.

The penetration and the fixation of essential oils in the product based on ovine dermic protein is caused by $\mathrm{NH}_{3}{ }^{+}$of proteins which favor the fixation of the essential oil after the transfer of its proton (Fig. 4).
The product had a very strong inhibitive activity on all the tested bacterial strains with average values of the diameter of the inhibition zones exceeding $16 \mathrm{~mm}$

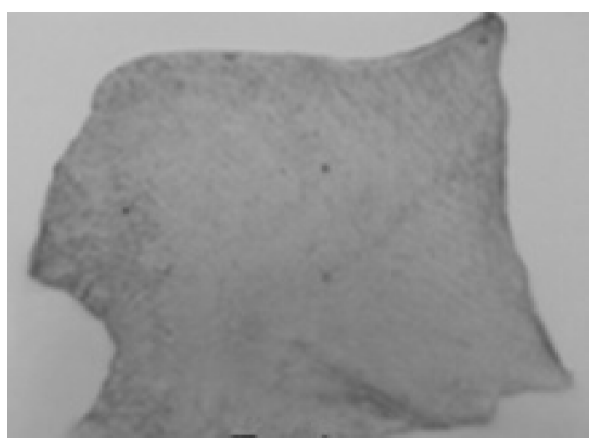

Fig.1 Ovine skin after deliming.

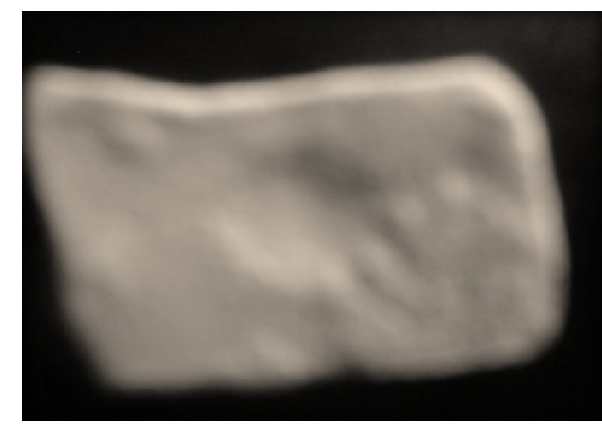

Fig. 2 Ovine protein semi-finished (after thermal processing).

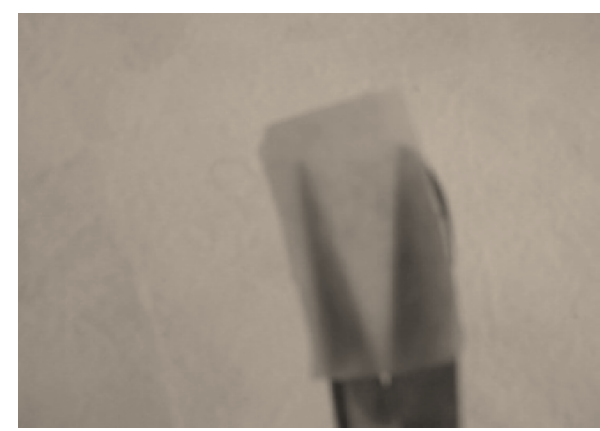

Fig. 3 Ovine protein, finished product.

Table 4 Test of the protein ovine product's antimicrobial activity [18].

\begin{tabular}{|c|c|c|c|c|c|c|c|c|c|c|}
\hline \multirow{3}{*}{$\begin{array}{l}\text { Batchs } \\
\begin{array}{l}\text { 1st batch Eucalyptus } \\
\text { globulus }\end{array}\end{array}$} & \multicolumn{10}{|c|}{ Means inhibition zone (mm) } \\
\hline & \multicolumn{2}{|c|}{$\begin{array}{l}\text { Staphylococcus } \\
\text { aureus }\end{array}$} & \multicolumn{2}{|c|}{ Escherichia coli } & \multicolumn{2}{|l|}{$\begin{array}{l}\text { Pseudomonas } \\
\text { aeruginosa }\end{array}$} & \multicolumn{2}{|c|}{$\begin{array}{l}\text { Klebsiellia } \\
\text { pneumoniae }\end{array}$} & \multicolumn{2}{|l|}{$\begin{array}{l}\text { Salmonella } \\
\text { heiderlberg }\end{array}$} \\
\hline & $19.5 \pm 0.1$ & +++ & $16 \pm 0.5$ & ++ & $16.3 \pm 0.32$ & + & $16.5 \pm 0.1$ & ++ & $16 \pm 0.1$ & ++ \\
\hline $\begin{array}{l}\text { 2nd batch Eugénia } \\
\text { caryophyllata }\end{array}$ & $25.5 \pm 0.5$ & +++ & $19.3 \pm 0.5$ & ++ & $19 \pm 0.10$ & ++ & $19.1 \pm 0.5$ & ++ & $19 \pm 0.41$ & ++ \\
\hline $\begin{array}{l}\text { 3rd batch Lavandula } \\
\text { officinalis }\end{array}$ & $22 \pm 0.2$ & ++ & $18.1 \pm 0.1$ & ++ & $19 \pm 0.26$ & ++ & $18 \pm 0.50$ & ++ & $18 \pm 0.21$ & ++ \\
\hline $\begin{array}{l}\text { 4th batch without } \\
\text { essential oil }\end{array}$ & $\mathrm{R}$ & - & $\mathrm{R}$ & + & $\mathrm{R}$ & - & $\mathrm{R}$ & - & $\mathrm{R}$ & - \\
\hline
\end{tabular}

* R: resistant, insensitive $(-)$, sensitive $(+)$, very sensitive $(++)$ and extremely sensitive $(+++)$. 


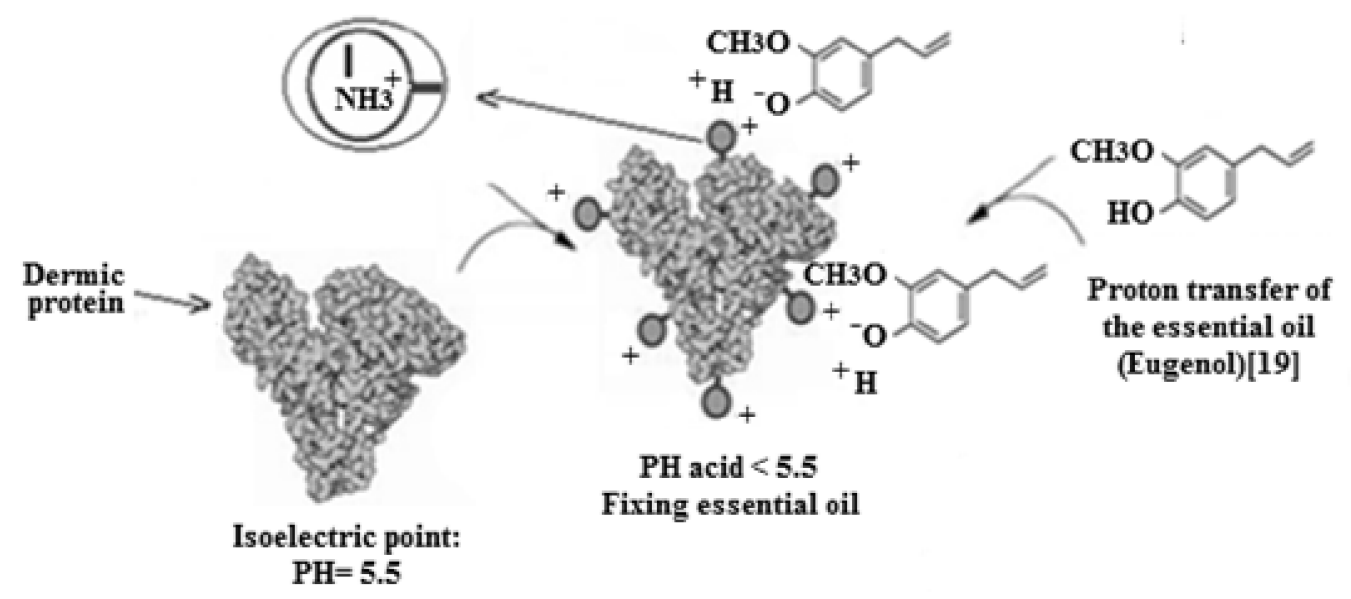

Fig. 4 Insights hypothetical schematic of the proton transfer mechanism of the essential oil.

for the 1st lot (Eucalyptus globulus). The Strains remained extremely sensitive for Staphylococcus aureus towards the 2nd lot Eugénia caryophyllata and the 3rd lot Lavandula officinalis. According to Kalemba, D., and Kunicka, A. [20], the sensibility of a microorganism to essential oil depends on the properties of the essential oil and on the microorganism itself. It is well known that bacteria Gram (+) are more sensitive to essential oils [21-23].

The first three batches gave a broad-spectrum antibacterial activity acting as well on bacteria Gram $(+)$ as Gram (-). The antibacterial properties of the main active components of essential oil (eugenol, 1,8-cineole (eucalyptol), linalool and acetata of linalyl) are in part related to their lipophilic characters, leading to the accumulation in the bacterial cell walls [23-25]. This engenders a disturbance on the functioning and the permeability of the cellular membranes, a degradation of the cellular wall [26, 27], damage to the cytoplasmic membrane and the cell content leaks [28-30].

On the other hand, the 4 th batch remained resistant.

\section{Conclusion}

This study has shown how dermal proteins can be obtained from a ovine skin. These proteins are transformed into an antimicrobial product which has biodegradable spongy structure with a transparent light yellow color and an aromatic, pleasant and spicy or fresh and spicy smell depending on the nature of the essential oil used, in particular eucalyptus (Eucalyptus globulus) the clove (Eugénia caryophyllata) and lavender (Lavandula officinalis). The product has a very strong inhibitory activity on all tested bacterial strains of Staphylococcus aureus, Escherichia coli, Pseudomonas aeruginosa, Klebseilla pneumoniae and Salmonella heiderlberg whose average values of the diameter of the inhibition zones is greater than $16 \mathrm{~mm}$. This is particularly true for product supplied by Eucalyptus globulus. The results are very promising, the strains remained extremely sensitive for Staphylococcus aureus towards the product supplied by Lavandula officinalis or Eugenia caryophyllata. The product gives a broad-spectrum antibacterial activity acting as well on bacteria Gram $(+)$ as Gram (-). It is easy to see that the product obtained can be used for medical purposes.

\section{Acknowledgments}

Nordine della for his invaluable advice in this research project.

\section{References}

[1] Mamerto, M., Cruz, Jr., John, H., LaVerne, T., and Tressler, C. 1977. Fibrous Collagen Derived Web Having Hemostatic and Woond. US Patent 4,016,877, filed February 23, 1976, and issued April 12,1977.

[2] Chavpil, M. C. 1974. Process for the Production of Collagen Fiber Fabrics in the Form of Felt-Like Membranes or Sponge-Like Layers. US Patent 3,823,212, 
filed May 28, 1971, and issued July 9,1974.

[3] Tadaaki, K. 1981. Method for Preparing Collagen Filaments for Use in Medical Treatments. US Patent 4,273,705. filed november 05, 1979, and issued June 16,1981 .

[4] Pariente, J. L., Villars, F., and Conort, P. 2005. "Chapter VII Biological Materials." Urology in Progress 5: 964-970.

[5] Terrence, R., and Green Jack, F. 1999. Medical Device Having Anti-infective and Contraceptive Properties. US Patent 6,939,569, filed June 18, 1999, and issued December $23,1999$.

[6] Richard Hait, M., and Aloysius Battista, O. 1973. Fibrous Collagen Derived Product Having Hemostatic and Wound Binding Properties. US Patent 3,742,955, filed September 29, 1970, and issued July 03, 1973.

[7] Jenny, G. 1994. "Preliminary Study of Résorbable Gentamicin Collagen Swabs with Delayed Antibiotic Release." Orthop Traumatol 4: 109-111.

[8] Sayed Ahmed, A., Mahmoud Al-refai, Alzahraa, O., and Emadeldin, M. K. 2016. "Antimicrobial Activities and the First Isolation of 4-nitrobenzoic Acid Tetrahydrofuran-2-yl-methylester and 4-hydroxy-5-methylfuran-3-one from Terrestrial streptomyces sp..” Int. J. Pharm. Bio. Sci. 7 (1): 45-55.

[9] Inouye, S., and Abe, S. 2007. "New Approach of Anti-infectious Aromatherapy." Phytotherapy 1: 2-4.

[10] Aloy, M., Folachier, M., Pichon, G., and Vulliemet, B. 1982. The Valuation of Tannery Waste and Tannery. France: National Agency for the Recovery and Disposal of Waste and Leather Technology Lyon Center.

[11] Piter Ries, E. 1983. Process for the Preparation of a Collagen Product for Medical and Cosmetic Purposes. US Patent 4,389,487, filed September 17, 1980, and issued June 21, 1983.

[12] Oussalah, M., Caillet, S., Saucier, L., and Lacroix, M. 2006. "Mechanism of Action of Spanish Oregano, Chinese Cinnamon and Savory Essential Oils on Escherichia Coli O157: H7 and Listeria Monocytogenes." Journal of food Protection 69 (5): 1046-1055.

[13] Ericsson, H. M., and Sherris, J. C. 1971. "Antimicrobial Susceptibility Testing-Report of an International Collaborative Study." Acta Pathol. Microbiol. Scand. 217: 1-90.

[14] Le Minor, L., and Veron, M. 1989. Medical Bacteriology, 2nd Edition. Paris: Flammarion.

[15] Burt, S. 2004. "Essential Oils : A Review." International Journal of Food Microbiology 94: 223-253.

[16] Pascale, A. 2003. Phyto-Aromatherap Guide. S.A.: Genitec Holding.

[17] Tharib, S. M., Gnan, S. O., and Veitch, G. B. A. 1983.
"Antimicrobial Activity of Compounds from Artemisia Campestris.” J. Food. Prot. 46: 681-685.

[18] Ponce, A., Fritz, G., and Delvalle, C. 2003. "SI Roura." Lebensmitell Wissenschaft and Technologie 36: 679-684.

[19] Dorman H. J. D., and Deans S. G. 2000. "Antimicrobial Agents from Plants: Antibacterial Activity of Plant Volatile Oils." Journal of Applied Microbiology 88: 308-316.

[20] Kalemba, D., and Kunicka, A. 2003. "Antibacterial and Antifumgal Properties of Essential Oils." Current Medicinal Chemistry 10: 813-829.

[21] Poole, K. 2001. "Multridrug Resistance in Gram Negative Bactéria." Curent Opinion in Microbiology 4: 500-508.

[22] Brut, S. A. 2004. "Essentiel Oils: Their Antibacterial Properties and Potentiel Application in Food." Journal of Food Microbiology 5: 22-25.

[23] Beckechi, C., Atik-Bekkara, F., and Ouahid, D. F. 2008. "Composition Antibacterial Activity of Essential Oils of Origanum Gldulosomm Algeria." Phytothérapie 6: 153-159.

[24] Helander, I. M., Alakomi, H. L., Latvala, K., Mattila-Sandholm, T., Pol, I., and Smid, E. J. et al. 1998. "Caractérisation of the Action of Selected Essentiel Oil Components Ongram-Negative Bacteria." Journal of Agrucultural and Food Chemistry 46 (9): 3590-3595.

[25] Knobloch, K., Paulia, Iberl, B., Weigand, H., and Weis, N. 1989. "Action of Terpenoids on Energy Metabolism." In Progress in Essential Oil Research, edited by Brunke, E. J. Berlin, Germany: Walter de Gruyter.

[26] Ultee, A., Bennik, M. H. J., and Moezelaar, R. 2002. "The Phenolic Hydroxyl Group of Carvacrol is Essential for Action against the Food-Borne Pathogen Bacillus Cerus." Appl. Environ. 68: 1561-1568.

[27] Juven, B. J., Karnner, J., Schved, F., and Weisslowiez, H. 1994. "Factors that Interact with the Antibacterial Action of the Thyme Essentiel Oil and Its Active Constituents." Journal of Applied Bactiriology 76: 626-631.

[28] Ultee, A., Kets, E. P. W., and Smid, E. J. 1999. "Mechanism's of Action of Carvacrol on the Food Borme Pathogène Bacillus Aereus." Applied and Environmental Microbiology 74: 233-238.

[29] Oos Terhaven, K., Poolman, B., and Smid, E. J. 1995. "S-carvone as a Natural Sprout Inhibiting, Fimgistatic and Bacterstatic Compood." Industriel Crops and Products 4: 23-31.

[30] Lambert, R. J. W., and Pearson, J. 2001. "Susceptility Testing: Accurate and Reproducible Minimum Inhibitory Concentration (MIC) and Non-inhibitory Concentration (NIC) Values." Journal of Applied Microbiology 88: 784-790. 